\title{
Potensi Aktinidin sebagai Pelunak Daging
}

\author{
Laudavian Dhanasatya ${ }^{1}$, Agnes Erlinda Novenia ${ }^{2}$, Warsono El Kiyat ${ }^{3}$ \\ ${ }^{I}$ Departemen Teknologi Pangan dan Gizi, Universitas Surya, Jl. MH. Thamrin Km 2.7, Banten, 15117 \\ E-mail: warsono.el.kiyat@gmail.com
}

\begin{abstract}
This study aimed to discuss the activity of actinidin in meat tenderization and to understand the ability of actinidin as a substitute for other tenderizing enzymes such as papain. Actinidin could be found in kiwi fruits with a similar structure and proteolytic activity characteristics to papain. The proteolytic activity of actinidin was found to be able to substitute papain in meat tenderizing without creating an off flavor side effect. However, increasing the actinidin concentration could enhance its proteolytic activity. Besides, actinidin also has the ability to hydrolyze collagen proteins and fibrinogens perfectly compared to papain activity.
\end{abstract}

Keywords —: actinidin; meat; tenderness.

\section{PENDAHULUAN}

Daging merupakan sumber asupan protein hewani dan juga penyedia kebutuhan vitamin dan mineral yang diperlukan tubuh. Kebutuhan asupan daging setiap individu berbeda-beda tergantung usia, jenis kelamin, status kesehatan, dan tingkat aktivitasnya (Tourney, 2013). Berdasarkan data Survei Sosial Ekonomi Nasional (SUSENAS), rata-rata konsumsi daging sapi di Indonesia sejak tahun 2010 hingga 2014 sebesar $2.402 \mathrm{~kg} / \mathrm{kapita} / \mathrm{tahun}$. Angka tersebut tergolong kecil bila dibandingkan dengan negara maju. Hal ini diperkirakan karena sebagian besar masyarakat Indonesia hanya mengonsumsi daging sapi pada hari besar keagamaan atau perayaan tertentu saja. Meskipun demikian, tingkat kebutuhan daging sapi nasional tetap mengalami peningkatan setiap tahunnya seiring dengan peningkatan kesadaran masyarakat terhadap pentingnya kebutuhan protein hewani (Kementerian Pertanian, 2017).

Dalam mengonsumsi daging, kelunakan merupakan salah satu parameter penting yang memengaruhi persepsi konsumen terhadap mutu daging (Chaurasiya et al., 2015). Parameter tersebut dapat diukur dari daya putus serat daging, yaitu semakin rendah nilai daya putusnya maka semakin lunak daging tersebut dan semakin mudah flavoring agent berpenetrasi ke dalam daging (Troy \& Kerry, 2010). Tahap pelunakan daging umumnya dapat dilakukan dengan proses marinasi ataupun dengan penambahan bahan pelunak daging, seperti protease. Enzim ini dinilai efektif dalam melunakkan daging, seperti salah satunya yaitu papain dihasilkan dari buah pepaya. Meskipun demikian, papain memiliki kecenderungan menyebabkan kelunakan yang berlebih pada permukaan daging. Umumnya, aplikasi papain atau enzim pelunak daging lain hanya dilakukan pada permukaan daging saja. Selain itu, papain cenderung memiliki rendemen yang rendah $(0,013 \%)$ dan dapat menyebabkan perubahan rasa pada daging (Ashie et al., 2002). Protease dari tumbuhan lain yang dinilai dapat menggantikan peranan papain adalah aktinidin yang dapat diekstraksi dari buah kiwi.

Buah kiwi (Actinidia deliciosa) pada mulanya adalah buah malaka, yang disebut sebagai kiwi sejak dipasarkan di Selandia Baru dan negara-negara barat (Bellwood et al., 1995). Secara artifisial, buah kiwi telah didomestikasi pada abad ke-20 dan hingga sekarang telah banyak varietas buah kiwi yang dikultivasi, yaitu sekitar 66 spesies buah kiwi di seluruh dunia. Kiwi dikonsumsi oleh hampir seluruh penduduk dunia, karena flavornya yang mudah diterima serta kaya nutrisi. Selain itu, dalam buah kiwi juga terkandung tiol proteinase atau disebut sebagai aktinidin dengan jumlah sekitar 50-60\% dari total protein larut air (Zhang et al., 2017). Aktinidin merupakan bagian dari papain dengan subfamili protease sistein yang terdiri dari bromelain dan fisin. Aktivitas protease yang dimiliki aktinidin ini mirip dengan kimosin dan papain, yaitu sebagai koagulan susu maupun keju, mencegah terjadinya pelunakkan daging berlebih, dan tidak memberikan off-flavor. Akan tetapi, penggunaan aktinidin sebagai pelunak daging ini diperlukan dalam kuantitas yang lebih banyak untuk menghasilkan kelunakan yang setara dengan penggunaan papain (Christensen et al., 2009; Zhang et al., 2017).

\section{AKTINIDIN}

Aktinidin (EC 3.4.22.14) merupakan enzim yang dikategorikan sebagai protease sistein yang mengandung gugus sulfhidril bebas yang berperan penting dalam aktivitas katalisisnya. Beberapa enzim lain yang termasuk dalam protease tiol/sulfhidril di antaranya: fisin, bromelain, dan papain. Karakteristik dari aktinidin yaitu aktif pada kisaran pH yang luas dan stabil suhu moderat. Akan tetapi, enzim ini rentan terhadap oksidasi, begitu juga dengan jenis protease tiol lain (Kaur et al., 2010).

Aktinidin aktif pada kisaran pH 3-6 dengan pH optimum 4, jika diaplikasikan pada makanan dengan gelatin sebagai substrat. Akan tetapi tetapi dengan substrat protein daging, aktivitas protease dari aktinidin bervariasi. Seperti pada aktin (protein globular) dan sebagian besar protein lain dapat terhidrolisis pada kisaran $\mathrm{pH} 3-4$, sementara miosin (protein fibrilar) terhidrolisis pada rentang pH yang lebih luas dari 3-8 (Nishiyama, 2007). Aktivitas aktinidin dapat dihambat dengan adanya inhibitor 
proteinase sistein. Umumnya, inhibitor tersebut yaitu: $\mathrm{Hg}^{2+}$, iodoasetat, 5,5'-ditiiobis- asam 2-nitrobenzoat (DTNB), dan 2piridil disulfida (Boland \& Singh, 2012).

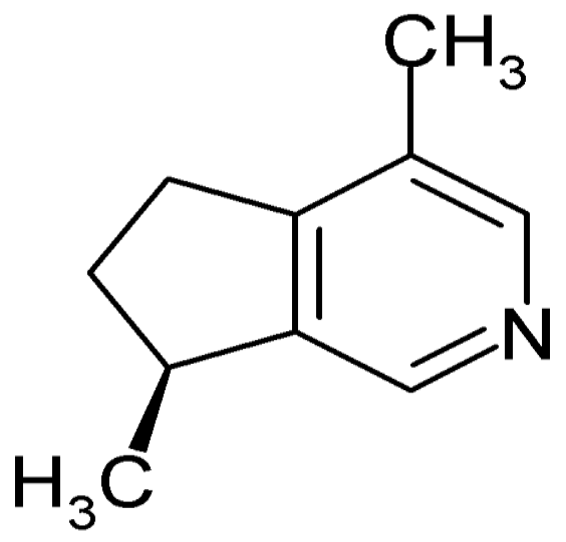

Gambar 1. Struktur kimia aktinidin (www.commons.wikimedia.org)

\section{III.PURIFIKASI AKTINIDIN}

Pada penelitian yang dilakukan oleh (Aminlari et al., 2009), untuk mengukut aktivitas aktinidin, perlu dilakukan purifikasi terlebih dahulu. Dalam hal ini, metode yang digunakan yaitu kromatografi pertukaran ion menggunakan kolom DEAE (Diethyl Amino Ethyl) sephadex. Prinsip dari metode ini yaitu pemisahan senyawa ion berdasarkan tingkat penyerapan secara reversibel dari molekul terlarut ke molekul lain yang berbeda muatan (Amersham Biosciences, 2004). Buah kiwi yang telah terpisah dari kulitnya dihomogenisasi, kemudian difiltrasi. Selanjutnya, larutan protein tersebut diendapkan dengan amonium sulfat agar konsentrasi enzim meningkat. Endapan yang diperoleh tersebut kemudian dilarutkan dengan buffer sitrat dan didialisis selama 1 malam pada suhu $4^{\circ} \mathrm{C}$. Selanjutnya, dialisat tersebut dimasukkan ke dalam kolom DEAE sephadex. Hasil dari purifikasi ini di antaranya: fraksi I (tube $n r 24$ to 36), fraksi II (tube $n r 45$ to 55), fraksi III (tube $n r 82$ to 90), dan fraksi IV (tube $n r$ 113 to 122). Namun, dia ntara beberapa fraksi tersebut hanya fraksi II yang memiliki puncak tertinggi seperti yang ditunjukkan pada Gambar 2 .

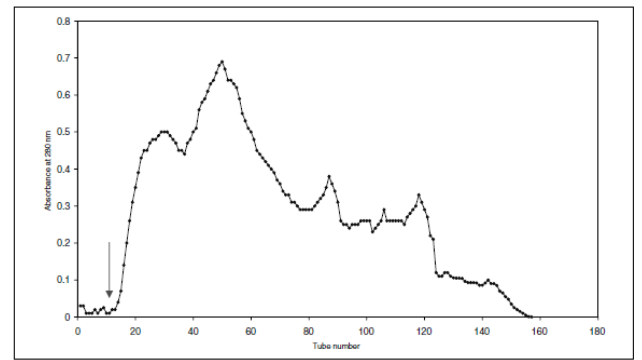

Gambar 2. Kromatogram berbagai fraksi (Aminlari et al., 2009)

\section{IV.IDENTIFIKASI AKTIVITAS PROTEOLITIK AKTINIDIN}

Menurut Zhang et al. (2017), pengujian aktivitas aktinidin dapat menggunakan larutan kasein sebagai substrat dan BSA (Bovine Serum Albumin) sebagai larutan protein standarnya. Sementara, pengukuran konsentrasi protein mengacu pada metode Lowry. Pada penelitian tersebut, ditemukan bahwa variasi pola protein pada ekstrak buah kiwi sangat tergantung dari jenis kultivarnya. Hasil ekstrak protein dari kultivar buah kiwi yang terbaik selanjutnya dipurifikasi. Kemudian, kemurnian enzim dapat diidentifikasi dengan menggunakan SDS Page.

Berdasarkan Gambar 3, pada observasi 29 kDa terhadap 7 kultivar tersebut ditunjukkan bahwa kultivar xuxiang memiliki intensitas terbesar dengan rata-rata berat molekul $22 \mathrm{kDa}$. Artinya, tingkat kemurnian kultivar tersebut cukup tinggi, karena telah mendekati rata-rata berat molekul standarnya $(29 \mathrm{kDa})$. Oleh karena itu, hasil penelitian menunjukkan bahwa kultivar xuxiang berpotensi untuk memberikan aktivitas protease tertinggi dan dapat digunakan untuk penelitian lebih lanjut. 


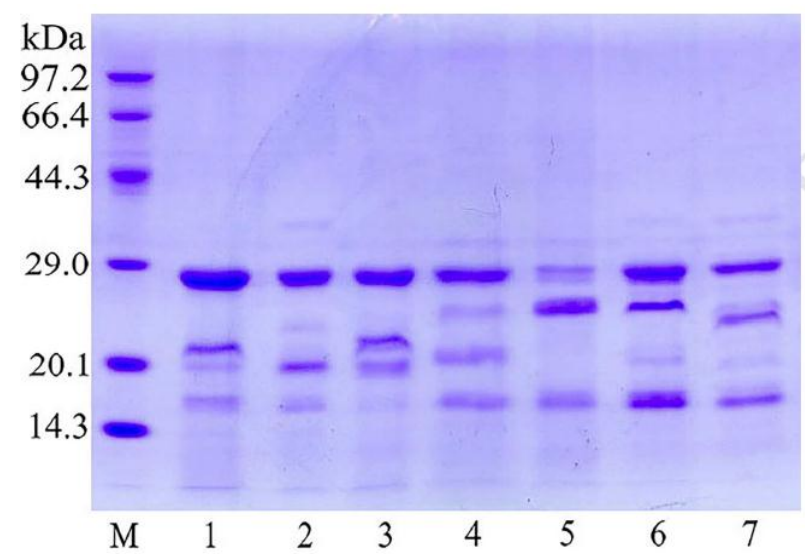

Gambar 3. Hasil dari SDS Page (1 = xuxiang, 2 = jinxiang, $3=$ hayward, 4 = jinyan, 5 = hongyang, $6=$ qihong, $7=$ jinlong i) $($ Zhang et al., 2017)

Selanjutnya, mengacu pada penelitian Aminlari et al. (2009), pengujian aktivitas aktinidin juga dapat dilakukan menggunakan substrat hemoglobin. Kemudian, sampel dianalisis dengan SDS-PAGE untuk mengetahui tingkat kemurnian sampel. Fraksi II hasil dari kolom DEAE Sephadex pada pengujian sebelumnya digunakan dan dibandingkan dengan ekstrak buah kiwi. Hasil yang ditunjukkan Gambar 4 menjelaskan bahwa fraksi II memiliki tingkat kemurnian paling tinggi dengan rata-rata berat molekul $23 \mathrm{kDa}$ atau mendekati standar $(29 \mathrm{kDa})$.

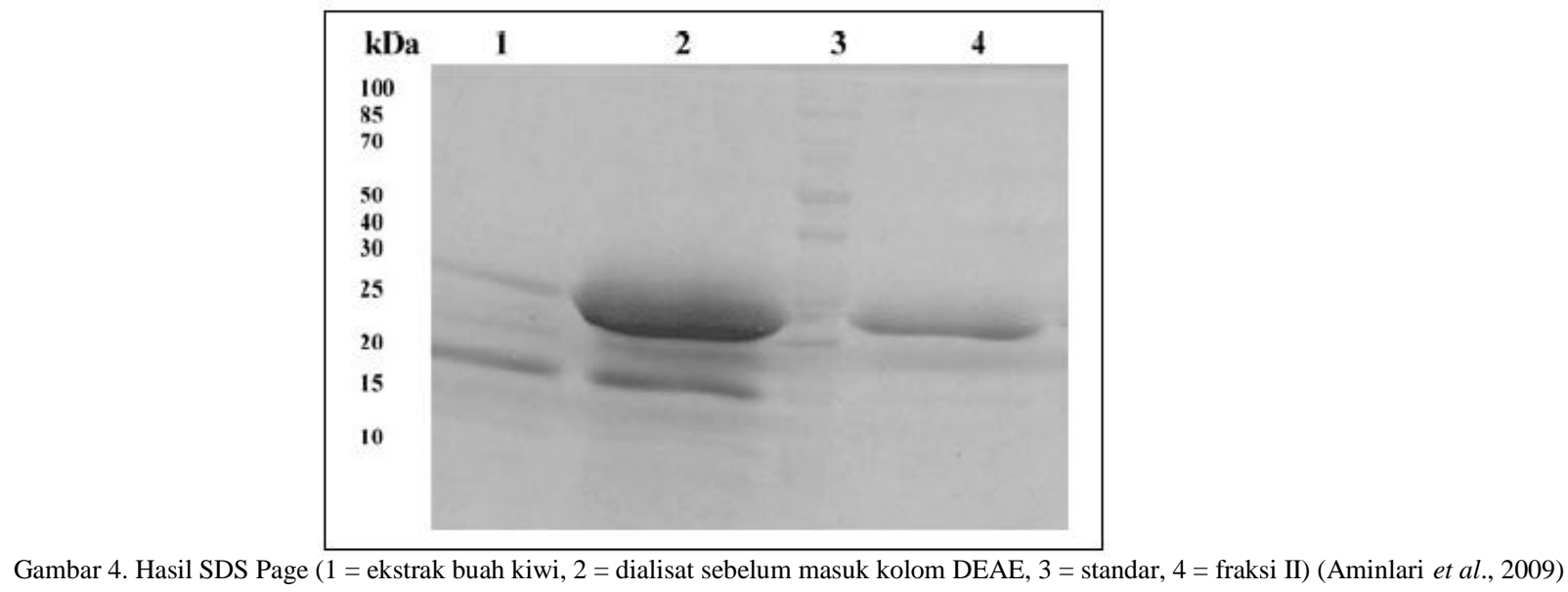

Diketahui juga bahwa fraksi II memiliki aktivitas spesifik yang tinggi meskipun konsentrasi proteinnya yang rendah, seperti yang ditunjukkan pada Tabel 1

Tabel 1.

Aktivitas spesifik aktinidin pada daging sapi (Aminlari et al., 2009)

\begin{tabular}{lcccc}
\hline \multicolumn{1}{c}{ Fraksi } & $\begin{array}{c}\text { Volume } \\
(\mathbf{m L})\end{array}$ & $\begin{array}{c}\text { Protein } \\
(\mathbf{m g} / \mathbf{m L})\end{array}$ & $\begin{array}{c}\text { Aktivitas } \\
(\mathbf{u n i t} / \mathbf{m L})\end{array}$ & $\begin{array}{c}\text { Aktivitas } \\
\text { unit/mg } \\
\text { protein }\end{array}$ \\
\hline $\begin{array}{l}\text { Ekstrak kiwi } \\
\text { segar }\end{array}$ & 100 & 16 & 1,62 & 0,10 \\
$\begin{array}{l}\text { Larutan } \\
\text { Terdialisis }\end{array}$ & 20 & 3,48 & 0,90 & 0,26 \\
$\begin{array}{l}\text { Fraksi I } \\
\text { Fraksi II }\end{array}$ & 39 & 0,35 & 0,08 & 2,23 \\
Fraksi III & 33 & 0,11 & 0,04 & 2,99 \\
Fraksi IV & 27 & 0,69 & 0,10 & 1,39 \\
\hline
\end{tabular}

Berdasarkan hasil penelitian Zhang et al., (2007), secara umum, aktivitas protease dari aktinidin dapat dikorelasikan dengan kadar protein, di mana tingkat aktivitas protease $A$. deliciosa berbanding lurus dengan kadar aktinidin dalam sampel. $A$. chinensis memiliki sifat yang lebih kompleks, di mana pengujian dengan SDS-PAGE menunjukkan bahwa peningkatan kadar aktinidin justru dapat menurunkan tingkat aktivitas proteasenya. Hasil penelitian Lewis dan Luh (1998) juga menjelaskan 
Website : http://agritek.unmermadiun.ac.id/index.php/agritek

bahwa meskipun kadar penambahan aktinidin diperlukan dalam kuantitas yang lebih banyak, namun penggunaan aktinidin tidak menyebabkan pelunakkan yang berlebih. Artinya, penggunaan aktinidin sebagai substitusi papain dan bromelain tidak menyebabkan tekstur daging menjadi terlalu lunak seperti yang terjadi saat menggunakan enzim bromelain atau papain.

Pengujian aktivitas protease terhadap beberapa jenis enzim komersil pelunak daging juga diuji oleh Minh, et al. (2012) yang menunjukkan bahwa terdapat perbedaan aktivitas protease yang signifikan dari masing-masing enzim. Dalam penelitiannya tersebut, ditunjukkan bahwa aktinidin memiliki efek hidrolisis protein miofibril yang paling efektif terhadap daging sapi dibandingkan dengan protease lain. Namun, aktinidin memerlukan jumlah yang lebih banyak untuk dapat mendapatkan hasil efektifitas yang sama dengan papain dan bromelain. Hal ini menunjukkan bahwa penggunaan enzim aktinidin dari buah kiwi sebagai pelunak komersil daging perlu dilakukan dengan memerhatikan konsentrasi efektif terhadap masing-masing sampel yang dilunakkan, terutama pada daging hewan selain sapi.

\section{EFEK AKTINIDIN PADA DAGING}

Chen et al. (2012) meneliti tentang efek dari penggunaan aktinidin pada daging babi. Hasil penelitian menunjukkan bahwa daging babi yang dimarinasi menggunakan protease buah kiwi menyebabkan degradasi pada protein kolagen dan perubahan pada indeks fragmentasi miofibril, ukuran partikel, dan viskositas. Selain itu,, ditemukan bahwa degradasi dan kelunakan dari daging babi yang dimarinasi menggunakan enzim aktinidin dengan konsentrasi yang berbeda dapat dikarakterisasi dengan beberapa jenis indikator yang berbeda. Viskositas menunjukkan korelasi yang berbanding lurus dengan indeks fragmentasi miofibril. Fragmentasi miofibril dapat dilihat dari pembentukan ukuran partikel yang semakin kecil (Gambar 5).

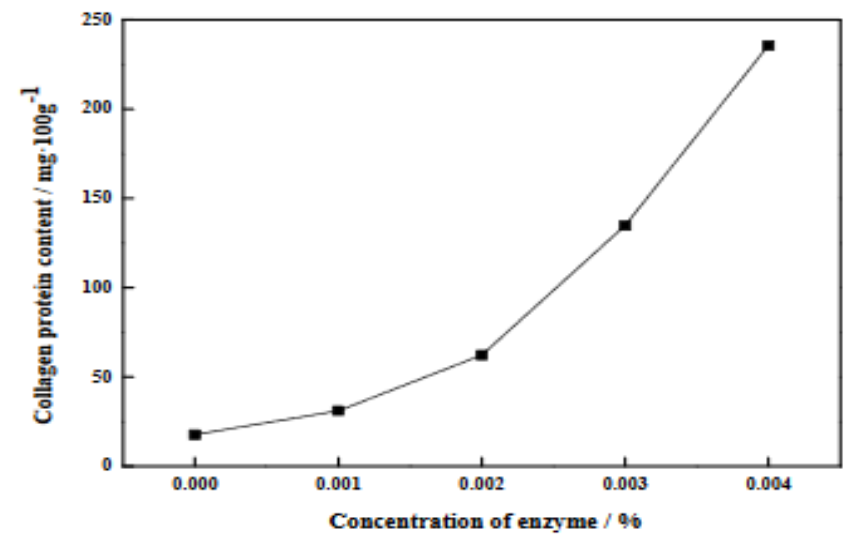

Gambar 5. Korelasi konsentrasi enzim aktinidin dengan degradasi kolagen (Chen et al., 2012)

Gambar 5 menunjukkan degradasi yang dilakukan oleh aktinidin terhadap daging babi memiliki sifat di mana konsentrasi aktinidin yang diberikan berbanding lurus dengan degradasi kolagen yang terjadi. Hal ini membuktikan bahwa sampel selain daging sapi memerlukan penyesuaian konsentrasi aktinidin yang diberikan, agar didapatkan hasil pelunakkan daging yang diinginkan.

Menurut Chalabi et al. (2014), imunoglobulin yang terdapat pada daging domba, kelinci, ayam, ikan, dan serum albumin susu kambing dapat dihidrolisis oleh aktinidin tanpa batasan efek proteolisis, yang merupakan salah satu kelemahan dari enzim papain. Pada penelitian tersebut, ditemukan bahwa aktinidin dapat menghidrolisis kolagen dan fibrinogen dengan sempurna pada $\mathrm{pH}$ netral, maupun pada keadaan sedikit basa. Hal ini menunjukkan bahwa aktinidin dapat digunakan sebagai protease yang dapat digunakan pada banyak aplikasi yang membutuhkan pelunakkan daging.

Berbeda dengan Zhang et al., (2007), untuk mengetahui sifat kelunakkan daging yang dihasilkan dapat diukur berdasarkan tingkat penyusutan massa daging selama pemasakkan. Umumnya, daging babi dan kelinci mengalami penyusutan massa selama proses pemasakkan berkisar antara 27-32\%. Tingkat penyusutan antara sampel yang diinjeksikan dengan air maupun protease tidak nampak jelas perbedaannya. Bila dibandingkan dengan standar, kedua sampel yang diinjeksikan baik dengan air maupun protease menunjukkan penyusutan yang lebih besar. Selain itu tingkat penyusutan tersebut berbanding lurus dengan konsentrasi yang diinjeksikan.

Pada penelitian Aminlari et al. (2009), ditemukan bahwa aktivitas proteolitik aktinidin lebih banyak ditemukan pada daging sapi dibandingkan jaringan ikatnya, seperti yang ditunjukkan pada Tabel 2. Semakin banyak aktinidin yang ditambahkan ke dalam daging maka semakin besar pula kapasitas penyerapan air dalam daging tersebut. Selain itu pada Tabel 3. dapat dilihat bahwa penambahan aktinidin dalam daging juga memberikan nilai yang lebih baik dari sisi organoleptik dan fisik, baik itu tekstur, rasa, aroma, warna, maupun kestabilitas emulsinya. 
Website : http://agritek.unmermadiun.ac.id/index.php/agritek

Tabel 2 .

Efek aktinidin terhadap kapasitas penyerapan air dan tekstur pada daging sapi (Aminlari et al., 2009)

\begin{tabular}{|c|c|c|c|c|c|}
\hline \multirow[t]{2}{*}{ Sampel } & \multirow{2}{*}{$\begin{array}{c}\text { Aktinidin (unit/g } \\
\text { beef) }\end{array}$} & \multicolumn{2}{|c|}{ NSI $(\%)^{\wedge}$ Waktu inkubasi (menit) } & \multirow[t]{2}{*}{ WHC (\%) } & \multirow[t]{2}{*}{ Daya tarik $\left(\mathrm{g} / \mathrm{cm}^{2}\right)$} \\
\hline & & 30 & 60 & & \\
\hline \multirow[t]{4}{*}{ Beef } & 0 & $36,5 \pm 1,3$ & $37,0 \pm 1,3$ & $50,6 \pm 1,7$ & $8,13 \pm 0,7$ \\
\hline & 0,3 & $39.0 \pm 0,8$ & $43,4 \pm 1,2$ & - & - \\
\hline & 0,6 & $43,5 \pm 2,4$ & $47,3 \pm 2,0$ & - & - \\
\hline & 0,9 & $46,2 \pm 3,9$ & $49,1 \pm 3,9$ & $54,7 \pm 1,2$ & $7,12 \pm 0,35$ \\
\hline \multirow[t]{4}{*}{ Jaringan penghubung } & 0 & $16,3 \pm 0,5$ & $13,8 \pm 0,9$ & - & - \\
\hline & 0,3 & $16,6 \pm 0,6$ & $14,0 \pm 0,9$ & - & - \\
\hline & 0,6 & $17,2 \pm 0,6$ & $15,4 \pm 0,9$ & - & - \\
\hline & 0,9 & $17,9 \pm 0,7$ & $13,1 \pm 0,9$ & - & - \\
\hline
\end{tabular}

Sung-Sil et al. (2014) melaporkan bahwa dalam aplikasinya pada daging babi, aktinidin dapat mendenaturasi dan menghidrolisis protein daging babi, meskipun tidak disebutkan apakah ada pengaruh yang signifikan terhadap perubahan kelunakan tekstur. Aktinidin memiliki kemampuan dalam mengurangi kadar porcine serum albumin (PSA) yang dikaitkan alergen pada daging babi setelah marinasi selama kurang lebih 4 jam dengan ekstrak buah kiwi.

Tabel 3.

Efek penambahan aktinidin terhadap sifat organoleptik dan karakteristik fisik daging sapi (Aminlari et al., 2009)

\begin{tabular}{lcc}
\hline \multicolumn{1}{c}{ Fraksi } & Volume $(\mathbf{m L})$ & $\begin{array}{c}\text { Protein } \\
(\mathbf{m g} / \mathbf{m L})\end{array}$ \\
\hline pH emulsi & $6,02 \pm 0,07$ & $6,07 \pm 0,12$ \\
pH sosis & $6,20 \pm 0,05$ & $5,92 \pm 0,27$ \\
Stabilitas emulsi & $7,30 \pm 0,40$ & $8,20 \pm 0,40$ \\
Tekstur $\left(\mathrm{g} / \mathrm{cm}^{2}\right)$ & $375 \pm 5,00$ & $405 \pm 10,0$ \\
Skor warna & $7,95 \pm 1,33$ & $8,45 \pm 1,62$ \\
Skor rasa & $7,91 \pm 1,29$ & $9,32 \pm 0,52$ \\
Skor tekstur & $8,00 \pm 1,61$ & $9,51 \pm 0,45$ \\
Skor odor & $7,77 \pm 1,38$ & $7,91 \pm 1,76$ \\
\hline
\end{tabular}

Kajian mengenai enzim-enzim protease pelunak daging yang dilakukan oleh Muhammad et al. (2016) menjelaskan beberapa hal mengenai perbandingan beberapa aktivitas protease, salah satunya adalah aktinidin. Penggunaan enzim aktinidin memiliki efek yang lebih rendah dibandingkan enzim protease pelunak daging lain. Oleh karena itu, perlu dikaji lebih lanjut mengenai keamanan penggunaan aktinidin mengingat FDA sendiri belum menyatakan bahwa enzim aktinidin aman untuk digunakan dalam bahan pangan.

\section{VI.KESIMPULAN}

Hasil kajian menyimpulkan bahwa aktinidin dapat digunakan sebagai substituen enzim pelunak daging lain seperti papain dan fisin. Enzim ini tidak memiliki efektivitas yang tinggi seperti papain atau fisin. Namun, penggunaan aktinidin dengan jumlah yang banyak dapat mendekati tingkat efektivitas papain dan fisin. Konsentrasi aktinidin di dalam daging berbanding lurus dengan aktivitas proteolitiknya. Dibandingkan dengan papain, aktinidin memiliki aktivitas proteolitik yang tidak terbatas pada protein globular dan dapat menghidrolisis kolagen dan fibrinogen secara sempurna pada pH netral dan basa. Aktinidin dapat menghidrolisis kolagen menjadi hidroksiprolin yang menyebabkan sifat shear force dari kolagen berkurang sehingga kelunakkan daging meningkat. Pada proteolisis miofibril, dihasilkan fragmen protein dengan rantai peptida yang lebih pendek, sehingga ikatan antar serat dapat mudah terpisah sehingga daging semakin lunak. Hal ini menunjukkan bahwa aktinidin cocok digunakan pada berbagai jenis aplikasi pengolahan pangan yang memerlukan pelunakkan daging. Perlu diingat bahwa penggunaan aktinidin belum diijinkan untuk digunakan secara komersil dan masih diperlukan kajian-kajian lebih lanjut untuk mengetahui tingkat keamanan penggunaannya.

\section{DAFTAR PUSTAKA}

Amersham Biosciences. (2004). Ion Exchange Chromatography \& Chromatofocusing: Principles \& Methods. Stockholm: Amersham Biosciences Limited. Aminlari, M., Shekarforoush, S., Gheisari, H., \& Golestan, L. (2009). Effect of Actinidin on the Protein Solubility, Water Holding Capacity, Texture, Electrophoretic Pattern of Beef, and on the Quality Attributes of a Sausage Product. Journal of Food Science, 74(3), $221-226$.

Ashie, L., Sorensen, T., \& Nielsen, P. (2002). Effects of Papain and a Microbial Enzyme on Meat Proteins and Beef Tenderness. Journal of Food Science, 67(6), $2138-2142$

Bellwood, P., Fox, J., \& Tryon, D. (1995). The Austronesians: Historical and Comparative Perspectives. Canberra.

Boland, M., \& Singh, J. (2012). Actinidain. In N. Rawlings \& Salvesen G (Eds.), Handbook of Proteolytic Enzymes (2nd ed., pp. 1879-1884). Amsterdam: Elsevier.

Chalabi, M., Khademi, F., Yarani, R., \& Mostafaie, A. (2014). Proteolytic Activites of Kiwifruit Aktinidin (Actinidia deliciosa cv. Hayward) on Different Fibrous and Globular Proteins: A Comparative Study of Aktinidin with Papain. Applied Biochemistry and Biotechnology, $172(8), 4025-4037$.

Chaurasiya, R., Sakhare, P., Bhaskar, N., \& Hebbar, H. (2015). Efficacy of Reverse Micellar Extracted Fruit Bromelain in Meat Tenderization. Journal Food Science Technology, 52(6), 3870-3880. 
Website : http://agritek.unmermadiun.ac.id/index.php/agritek

Chen, Y., Zhang, Q., Lin, X., \& Liao, X. (2012). Valuation and Characterization of Aktinidin Treatment to Pork. Advanced Materials Research, 554-556, $1258-1261$.

Christensen, M., Torngren, M., Gunvid, A., Rozlosnik, N., Lametsch, R., Karlsson, A., \& Ertbjerg, P. (2009). Injection of Marinade with Aktinidin Increases Tenderness of Porcine M. biceps femoris and Affects Myofibrils and Connective Tissue. Journal of the Science of Food and Agriculture, 89(9), 16071614.

Kaur, L., Rutherfurd, S., Moughan, P., Drummond, L., \& Boland, M. (2010). Actinidin Enhance Gastric Protein Digestion as Assessed Using an in Vitro Gastric Digestion Model. Journal of Agricultural and Food Chemeistry, 58(8), 5068-5073.

Kementerian Pertanian. (2017). Outlook Komoditas Pertanian Subsektor Peternakan Daging Sapi. (A. A. Susanti \& A. Akbar, Eds.). Jakarta: Pusat Data dan Sistem Informasi Pertanian Sekretariat Jenderal Kementerian Pertanian.

Lewis, D., \& Luh, B. (1998). Application of Aktinidin from Kiwifruit to Meat Tenderization and Characterization of Beef Muscle Protein Hydrolysis. Journal of Food Biochemistry, 12(3), 147-158

Minh, H., Alaa, E., Alan, C., \& David, L. (2012). Characterisation of Commercial Papain, Bromelain, Aktinidin, and Zingibain Protease Preparations and Their Activities toward Meat Proteins. Food Chemistry, 134(1), 95-105.

Muhammad, S., Joong-Ho, K., Muhammad, I., \& Muhammad, S. (2016). Plant and Bacterial Proteases: A Key towards Improving meat Tenderization, A Mini Review. Cogent Food and Agriculture, 2, 1261780.

Nishiyama, I. (2007). Fruits of the Actinidia Genus. Advances in Food and Nutrition Research, 52, 293-324.

Sung-Sil, M., Dongwook, K., Il-Suk, K., Jun-Sang, H., Beom-Young, P., \& Aera, J. (2014). Alteration of Porcine Serum Albumin Levels in Pork Meat by Marination in Kiwi or Pineapple Juice and Subsequent Pan Broiling. Korean Journal of Food Scienece Animal Resource, 34(3), 355-361.

Tourney, A. (2013). USDA Serving Size Requirements for Meat. Retrieved February 18, 2019, from www.livestrong.com/article/352790-usda-meat-servingsize-requirements/

Troy, D., \& Kerry, J. (2010). Consumer Perception and the Role of Science in the Meat Industry. Meat Science, 86(1), 214-226.

Zhang, B., Sun, Q., Liu, H., Li, S., \& Jiang, Z. (2017). Characterization of Aktinidin from Chinese Kiwifruit Cultivars and Its Applications in Meat Tenderization and Production of Angiotensin 1-Converting Enzyme (ACE) Inhibitory Peptides. LWT - Food Science and Technology, 78, 1-7. 